\title{
2D MODELOVANIE ZAPLAVENIA ŠTRKONOSNÉHO VODNÉHO TOKU TOPLA (ZÁPADNÉ KARPATY)
}

\author{
Miloš Rusnák, Anna Kidová, Lukáš Michaleje
}

\begin{abstract}
Main aim of the paper was inundation 2D modeling of gravel-bed and lateral dynamic Topl'a River in flysch Western Carpathians. Results points to 473.20 ha of flooded area during flood event from 2010 with recurrence interval 100 years. Average water depth on floodplain in the river channel was $0.7 \mathrm{~m}$ and $2.8 \mathrm{~m}$. Extent of the inundation during one-year recurrence interval was $160.8 \mathrm{ha}$, which was flooded during low magnitude floods. Knowledge of the long-term evolution of river morphology and hydraulic modeling is a major challenge for the understanding of river ecosystems in the future and application of such kind of interventions that lead to improving ecological status of ecosystem and minimizing the negative effects of floods.
\end{abstract}

Keywords: Topl'a River, HEC RAS, inundation, morphology

\section{Úvod}

Výskum v oblasti povodňového rizika a brehovej erózie vodných tokov a ich manažmentu púta stále väčšiu pozornost' tak zo strany vedeckej komunity ako aj širokej verejnosti. Hlavným faktorom, ktorý zvyšuje potrebu dôkladnejšie sa venovat' povodňovému riziku a zmenám morfológie vodných tokov, sú klimatické zmeny. Očakáva sa zmena $\mathrm{v}$ prejavoch počasia, ktoré bude mat' omnoho extrémnejší priebeh a následky. Okrem častejších a dlhších periód sucha počas roka, sú očakávané dažde, ktoré $\mathrm{v}$ kratších časových úsekoch prinesú viac atmosférických zrážok (IPCC, 2014, Damborská et al., 2016). Druhým dôvodom pre výskum povodňového rizika a efektu brehovej erózie sú zmeny vo využívaní zeme, ktoré ovplyvňujú tvorbu odtoku v povodí. Nižší podiel lesných plôch $\mathrm{s}$ vysokou retenčnou kapacitou alebo nevhodné obhospodarovanie pôdy vedúce $\mathrm{k}$ nízkej infiltračnej kapacite pôdy, vedú $\mathrm{k}$ rýchlejšiemu odtoku vody z povodia (cf. Valent a kol., 2017). Nadmerné množstvo nepriepustných plôch v intraviláne zabraňuje akémukol'vek vsakovaniu. Ďalším faktorom vplývajúcim na povodňové riziko sú zmeny v morfológií riečnych korýt a pririečneho priestoru. Regulácia korýt vodných tokov, v podobe narovnávania, priamo vplýva na zvýšenie rýchlosti prúdenia vody a taktiež aj na transport sedimentov (Wyžga, 1993). Takto vzniká vyššie povodňové riziko na nižších častiach vodného toku a zároveň potreba budovania d'alších protipovodňových opatrení. 
Hodnotenie povodňového rizika predstavuje racionálny základ pre integrovaný manažment povodňového rizika (Solín et al., 2018). Pre redukciu povodňového rizika je preto potrebné poznat' jeho vel'kost', charakter a priestorové rozmiestnenie. Vel'kost' povodňového rizika pre danú oblast' nám určuje jeho mieru, a zvyčajne povodňové riziko škálujeme rozsahom od nízkeho až po vysoké. Charakter definuje, ktorá zo zložiek povodňového rizika je dominantná. $\mathrm{Na}$ základe priestorového rozmiestnenia vieme určit' najrizikovejšie oblasti. Hodnotenie povodňového rizika je preto nevyhnutným podkladom pre vytvorenie stratégie redukcie povodňového rizika v povodí (Merz et al., 2014). Súčastou stratégie sú opatrenia na redukciu povodňového ohrozenia, redukciu zranitel'nosti alebo redukciu negatívnych následkov povodní (APFM, 2004). Samotné hodnotenie povodňového rizika vzniká kombináciou hodnotenia povodňového ohrozenia a hodnotenia zranitel'nosti (Bouma et al., 2005; Gouldby et al., 2005). Povodňové ohrozenie predstavuje prírodný živel (povodeň), ktorý môže spôsobit' stratu na životoch, škody na majetku, prerušenie sociálnych alebo ekonomických sietí a aktivít (UN/ISDR, 2004). Zranitel'nost' je náchylnost' na poškodenie spôsobené ohrozením na konkrétnom mieste, ako aj potenciál pre sociálne narušenie takouto udalost'ou (Borden et al., 2007).

Prvou čast'ou hodnotenia povodňového rizika je identifikácia ohrozených oblastí. V oblastiach, ktorých obyvatelia majú častú skúsenost' so záplavami sa najprv vykonáva hodnotenie povodňového ohrozenia. V ohrozených oblastiach je následne hodnotená zranitel'nost' sociálneho ekonomického a environmentálneho systému. Samotné hodnotenie povodňového ohrozenia sa dá vyjadrit' ako kumulatívna distribučná funkcia rozdelenia maximálnych prietokov $\mathrm{Q}_{\max } \mathrm{F}(\mathrm{q}), \mathrm{v}$ ktorej je vyjadrená pravdepodobnost', s akou maximálny ročný prietok $\mathrm{Q}_{\max }$ neprekročí špecifickú hodnotu q.

$$
\mathrm{F}(\mathrm{q})=\mathrm{P}(\mathrm{Qmax} \leq \mathrm{q})
$$

Z tejto rovnice vyvstáva prvý problém hodnotenia povodňového rizika a tým je stanovenie N-ročných maximálnych prietokov, ktoré je možné určit' empiricky z nameraných dát, na základe zrážkovo odtokových modelov alebo na základe štatistických metód, akými sú napr. regionálna frekvenčná analýza (Vojtek, 2014). Druhým krokom je stanovenie výšky hladiny odpovedajúcej Nročným maximálnym prietokom, $\mathrm{k}$ čomu sa využíva hydraulické modelovanie. $\mathrm{Na}$ základe vstupných dát je možné vytvorit' $1 \mathrm{D}, 2 \mathrm{D}, 2.5 \mathrm{D}$ alebo $3 \mathrm{D}$ hydraulický model. Posledným krokom je spojenie výsledkov hydraulického modelu s digitálnym modelom reliéfu. Výstupom tohto procesu je vymedzenie rozsahu zaplavenia.

Druhým aspektom zvýšenej energie vodných tokov je brehová erózia, ktorá sa prejavuje laterálnym posunom ich korýt (Hooke, 2003). Brehová erózia je úzko prepojená s povodňovými udalost’ami, ktoré zvyšujú energiu vodného toku, čo sa 
prejavuje výraznejšími geomorfologickými účinkami a zvýšenou mierou eróznoakumulačných procesov v koryte (Hooke, 1979, Miller, 1990). Avšak ako uvádza Fuller (2005) je nevyhnutné odlišovat' dva efekty povodne, a to inundáciu územia a brehovú eróziu. Samotná laterálna migrácia vytvára pre človeka nebezpečenstvo, ktoré ohrozuje jeho aktivity (napr. využívanie zeme, záber vlastníctva pôdy) a deštruuje stavby, cesty, mosty, domy a pod. (Piégay et al., 1997). Považovaná je za prírodný hazard, pred ktorým sa človek chráni rôznymi technickými (inžinierskymi) a netechnickými (zelenými) zásahmi do koryta (Piégay et al., 2005). Úspešný a udržatel'ný manažment vodných tokov vyžaduje pochopenie, ktoré úseky toku sú náchylnejšie na deštrukciu brehu a následný laterálny posun.

Ciel'om príspevku je na základe 2D modelovania identifikovat' rozsah zaplavenia pre úsek rieky Topl'a v okolí mesta Bardejov pre laterálne nestabilné, štrkonosné a málo regulované kl’ukatiace sa koryto. Druhotným aspektom je otestovat' presnost' rozsahu zaplavenia pomocou hydrodynamického 2D modelovania v prostredí HEC RAS.

\section{Lokalizácia územia}

Topl'a predstavuje na Slovensku jedinečnú rieku, ktorá má dynamické a málo regulované koryto (Rusnák a Lehotský, 2014, Rusnák et al., 2016). Pramení v pohorí Č́ergov vo výške $930 \mathrm{~m} \mathrm{n}$. m. a po sútok s Ondavou dosahuje dížku $115 \mathrm{~km}$. Plocha jej povodia predstavuje $1506,4 \mathrm{~km}^{2}$. Dlhodobý priemerný denný prietok $\mathrm{v}$ stanici Bardejov sa pohybuje na úrovni $3 \mathrm{~m}^{3} \cdot \mathrm{s}^{-1}$, avšak maximálny kulminačný prietok povodne $\mathrm{z}$ roku 2010 dosiahol úroveň $350 \mathrm{~m}^{3} \cdot \mathrm{s}^{-1}$. Skúmané územie sa nachádza vo flyšovej časti Ondavskej vrchoviny vonkajších Karpát na severe Slovenska pri meste Bardejov (obr. 1) a predstavuje dížku 21,5 km. Niva je z oboch strán ohraničená výraznými svahmi, ktoré sú na mnohých miestach postihnuté zosuvmi. Typickým prejavom laterálnej dynamiky Tople je brehová erózia a degradácia koryta, ktorá sa prejavuje zúžením šírky aktívneho koryta $\mathrm{z}$ 62,1 m (1949) na 37,2 m. Tento trend potvrdzuje aj pokles plochy štrkových lavíc. Antropogénne ovplyvnený úsek koryta sa nachádza v meste Bardejov o celkovej dížke $5 \mathrm{~km}$. Výsledkom historických zmien je transformácia širokého a migrujúceho koryta na úzky meandrujúci vodný tok $\mathrm{s}$ vyvinutým ripariálnym pásom. Rovnako ako $\mathrm{v}$ minulosti, tak aj $\mathrm{v}$ súčasnosti sa niva vodného toku intenzívne pol'nohospodársky využíva. 
Obr. 1: (a) Lokalizácia skúmaného územia v rámci Slovenska; (b) ortofotosnímka záujmového územia Tople v okolí Bardejova; (c) porovnanie morfológie koryta ned'aleko Mokroluhu V roku 1949 a (d) V roku 2013; (e) fotografia protipovodňovej úpravy $\mathrm{v}$ meste Bardejov a (f) brehovej steny v mieste bočnej erózie

Fig. 1: (a) Location of the surveyed territory within Slovakia; (b) Orthophotos of the Topla area in the vicinity of Bardejov; (c) Comparison of morphology of the bed near Mokroluh in 1949 and (d) in 2013; (e) Photo of flood control in the town of Bardejov and (f) Bank wall in the site of lateral erosion

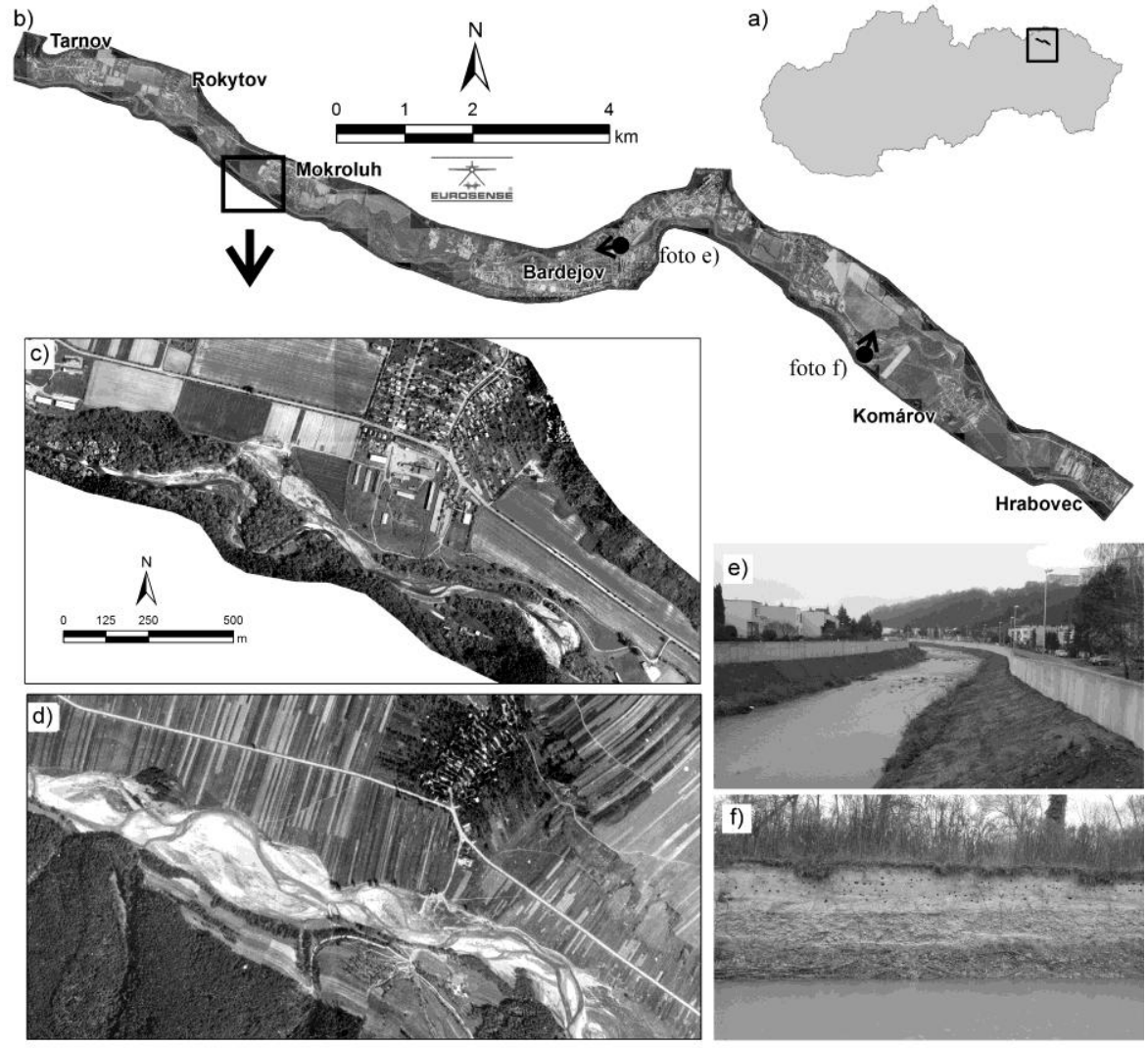

Zdroj: Ortofotomapa CEUROSENSE, s r. o., Historickú ortofotomapu zabezpečila Technická univerzita vo Zvolene; Historická ortofotomapa CGEODIS SLOVAKIA, s r. o., EUROSENSE, s r. o.; historické LMS @Topografický ústav Banská Bystrica 


\section{Metódy}

\section{Hydrologické dáta}

Pre hydraulické modelovanie boli použité hodinové hydrogramy $\mathrm{z}$ katastrofickej povodne z roku 2010 zo štyroch vodomerných staníc pre časovú periódu od 30.05.2010 (00:00) do 08.06.2010 (23:00) poskytnuté SHMÚ (Obr. 2). Stanica v Gerlachove (maximálny prietok $78,94 \mathrm{~m}^{3} \cdot \mathrm{s}^{-1}$ ) sa nachádza na začiatku skúmaného územia (približne $3 \mathrm{~km}$ nad sledovaným úsekom) a stanica v Bardejove je situovaná v strede modelového územia (maximálny prietok $351,2 \mathrm{~m}^{3} \cdot \mathrm{s}^{-1}$ ). Ďalšie dve stanice sa nachádzajú na prítokoch Šíbska Voda (stanica Kl’ušov - Kl’ušovská Zábava $\mathrm{s}$ povodňovým prietokom $65,48 \mathrm{~m}^{3} \cdot \mathrm{s}^{-1}$ ) a Kamenec so stanicou $\mathrm{v}$ Bardejovskej Dlhej Lúke (prietok 42,29 $\mathrm{m}^{3} \cdot \mathrm{s}^{-1}$ ).

Graf 1: Hydrogram povodňovej udalosti z roku 2010 pre vodomerné stanice Gerlachov, Bardejov, Bardejovská Dlhá Lúka a Kl’ušov - Kl’ušovská Zábava Graph 1: Hydrograph of the 2010 flood event for the Gerlachov, Bardejov, Bardejovská Dlhá Lúka and Kl'ušov - Kl'ušovská Zábava water stations

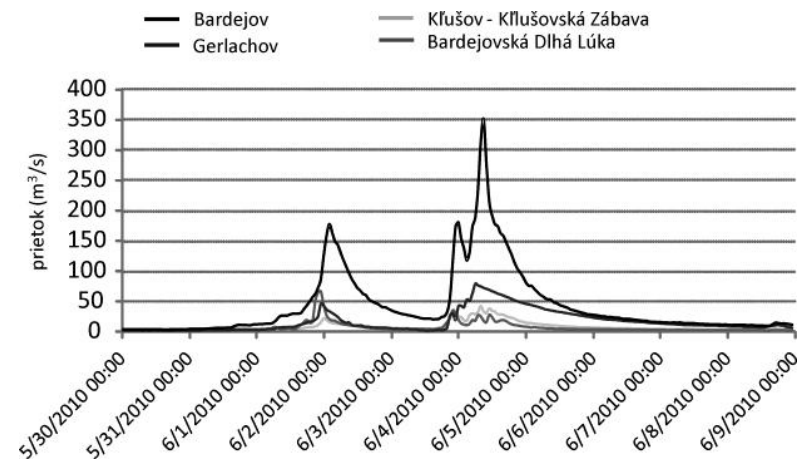

\section{Zdroj: SHMÚ}

\section{Terénny prieskum}

Pre identifikáciu tvaru koryta pod vodnou hladinou boli v sledovanom území geodeticky zamerané priečne profily, pričom vyššia hustota bola lokalizovaná $\mathrm{v}$ miestach zmeny morfológie koryta a $\mathrm{v}$ morfologicky nepravidelných úsekoch s presnostou $+/-1 \mathrm{~cm}$. Každému priečnemu profilu bol priradený aj lokálny sklon. Priečny profil pozostával s minimálne 15 bodov, ktoré mali zamerané súradnice $\mathrm{x}, \mathrm{y}$ a $\mathrm{z}$. Jednotlivé body zároveň identifikovali výrazné hrany a zmeny morfológie koryta a celkovo bolo zameraných 95 profilov. V rámci terénneho prieskumu sa identifikovali erózne brehy, antropogénne štruktúry $\mathrm{v}$ koryte (mosty, hrádze, hate, opevnenia brehu), výška hladiny a výška línie odpadu. 


\section{Digitálny model terénu}

Základným zdrojom priestorových údajov pre modelovanie bol digitálny výškový model v TIN formáte (obr. 2) fotogrametricky derivovaný z leteckých meračských snímok s rozlíšením pixla $10 \mathrm{~cm}$, ktorý bol získaný od firmy EUROSENSE s r. o.. Ked’že fotogrametrický model nie je schopný zachytit' tvar koryta pod vodnou hladinu, digitálny model bol následne upravený vložením digitálneho modelu koryta, ktorý bol vypočítaný interpoláciou tvaru koryta získaného $\mathrm{z}$ priečnych profilov. $\mathrm{V}$ poslednom kroku sa digitálny model upravil vsunutím 3D modelu budov, ktorý bol získaný z priestorovej databázy ZB GIS, kde sa využila polygónova vrstva budov s atribútom výška budovy. Finálny digitálny model mal výsledné rozlíšenie rastra $0,5 \mathrm{~m}$.

Obr. 2: (a) Digitálny model terénu s rozlíšením $0,5 \mathrm{~m}$, (b) digitálny model $\mathrm{s}$ vloženým batymetrickým modelom koryta a (c) výsledný model, ktorý vznikol kombináciou modelu, batymetrie a budov

Fig. 2: (a) Digital terrain model with a resolution of $0.5 \mathrm{~m}$, (b) a digital model with inserted bathymetric model of the channel and (c) resulting model that was created by a combination of model, bathymetry and buildings

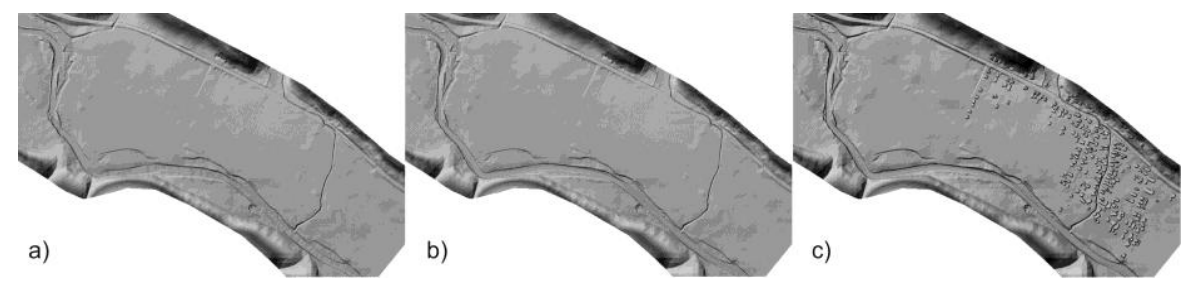

Zdroj dát: CEUROSENSE, s r. o. a Mapový podklad CÚrad geodézie, kartografie a katastra Slovenskej republiky 19-102-646/2018

\section{Hydrodynamické modelovanie}

Hydrodynamické modelovanie prebiehalo v prostredí programu HEC RAS 5.0.1., ktorý umožňuje 2D modelovanie zaplavenia územia. Príprava dát prebiehala v prostredí ArcGIS (extenzia HEC-GeoRAS), ktorá slúži pre základné úpravy a export dát do prostredia HEC RAS. Jednotné dátové vrstvy boli spracované v SJTSK (Krovak East North) koordinačnom systéme a do modelovania vstupovali hydrogramy modelovanej povodňovej udalosti, výškový model s vloženým modelom dna koryta a údaje o krajinnej pokrývke, ktoré slúžili pre výpočet drsnosti koryta. Finálne geometrické úpravy koryta, vloženie mostov a hatí prebiehali už v softvéri HEC RAS, kde sa pre 2D modelovanie v geometrickom editore najprv vytvorí mesh (výpočtový grid) s rozlíšením $25 \mathrm{~m}$, ktorý bol následne upravený vložením výrazných terénnych hrán s rozlíšením gridu 10 x $10 \mathrm{~m}$. 
Drsnost' koryta bola určená na základe krajinnej pokrývky priradením Manningovho súčinitel’u drsnosti. Na začiatku skúmaného územia a jednotlivých prítokov v miestach vodomerných staníc boli určené tri okrajové podmienky (Flow Hydrograph na začiatku skúmaného územia a dvoch hlavných prítokoch), do ktorých vstupovala informácia o prietokoch. Na konci skúmaného územia $\mathrm{v}$ poslednom profile sme využili okrajovú podmienku: kritická híbka. Pre modelovanie povodňovej vlny bolo vybrané neustálené prúdenie (unsteady flow analysis) s výpočtovým krokom 10 sekúnd a modelové scenáre pre povodňovú vlnu s prietokom $\mathrm{Q}_{1}, \mathrm{Q}_{5}, \mathrm{Q}_{10}, \mathrm{Q}_{20}, \mathrm{Q}_{50}$ a $\mathrm{Q}_{100}$. Model bol kalibrovaný úpravou Manningovho súčinitel'u drsnosti, tak aby sa modelovaný prietok zhodoval $\mathrm{s}$ priebehom povodňovej vlny vo vodomernej stanici v Bardejove (načasovanie a vel'kost' maximálneho prietoku).

\section{Výsledky}

\section{Plocha zaplavenia}

Výsledkom modelovania je mapa plôch zaplavenia pre jednotlivé povodňové vlny definované N-ročným prietokom. Plocha zaplavenia pre $\mathrm{Q}_{100}$ bola vo vybranom území 473,20 ha, z toho 376,53 ha tvorilo samotné zaplavenie nivy, mimo priestoru súčasného koryta (tab. 1). Maximálna híbka vody pre rozsah $\mathrm{Q}_{100}$ bola na nive $4,5 \mathrm{~m}$ a v koryte o $30 \mathrm{~cm}$ viac. Priemerná híbka vody na nive sa pohybovala na úrovni $70 \mathrm{~cm}$, pričom $\mathrm{v}$ koryte to bolo až $2,8 \mathrm{~m}$. S poklesom vel'kosti povodňovej vlny rozsah zaplavenia, ako aj híbka vody v koryte na nive postupne klesá až na úroveň 160,8 ha a priemernú híbku 1,6 m v koryte a $50 \mathrm{~cm}$ na nive.

Tab. 1: Plocha zaplavenia a maximálny prietok v záverovom profile pre jednotlivé N-ročné prietoky

Table 1: Flooded area and maximum discharge in the final profile for individual $\mathrm{N}$ year discharges

\begin{tabular}{|c|c|c|c|c|c|c|c|}
\hline & & $\mathbf{Q}_{1}$ & $Q_{5}$ & $Q_{10}$ & $\mathbf{Q}_{20}$ & $Q_{50}$ & $Q_{100}$ \\
\hline \multirow{2}{*}{\multicolumn{2}{|c|}{$\begin{array}{l}\text { zaplavená plocha } \\
\text { (ha) } \\
\text { maximálny prietok } \\
\left(\mathrm{m}^{3} / \mathrm{s}\right)\end{array}$}} & 160,80 & 252,40 & 292,00 & 344,10 & 414,50 & 476,20 \\
\hline & & 116 & 163 & 193 & 231 & 310 & 378 \\
\hline \multicolumn{2}{|c|}{ zaplavená plocha nivy (ha) } & 61,13 & 152,73 & 192,33 & 244,43 & 314,83 & 376,53 \\
\hline \multirow{2}{*}{$\begin{array}{l}\text { koryto - híbka vody } \\
\text { (m) }\end{array}$} & $\max$ & 3,2 & 3,4 & 3,7 & 4 & 4,5 & 4,8 \\
\hline & priem & 1,6 & 2 & 2,1 & 2,3 & 2,6 & 2,8 \\
\hline \multirow{2}{*}{$\begin{array}{l}\text { niva - híbka vody } \\
\text { (m) }\end{array}$} & $\max$ & 2,9 & 3,2 & 3,4 & 3,7 & 4,2 & 4,5 \\
\hline & priem & 0,5 & 0,5 & 0,5 & 0,54 & 0,64 & 0,7 \\
\hline
\end{tabular}


Značne vel'ký rozsah zaplavenia je dosahovaný aj pri prietoku $\mathrm{Q}_{1}$, pri ktorom dochádza $\mathrm{k}$ zaplaveniu nivy na ploche 61,13 ha. $\mathrm{K}$ vybreženiu vody pre $\mathrm{Q}_{100}$ dochádza v celom rozsahu ripariálnej zóny v oblasti lužného lesa (obr. 3). V západnej časti skúmaného územia, nad Bardejovom, hranica zaplaveného územia siaha po hranice obcí Tarnov, Rokytov a Mokroluh, kde dochádza k zaplaveniu záhrad a hospodárskych budov. Najväčší rozsah zaplavenia dosahuje Topl'a nad Bardejovom v časti Pod Dúbravou, kde dosahuje zaplavovaná oblast’ šírku až 725 $\mathrm{m}$ a zaberá skoro celú čast' doliny, pričom zaplavuje viacero studní vodných zdrojov. V meste Bardejov hranica zaplaveného územia siaha na l’avej strane až po úpätie doliny a zaplavuje zimný štadión, zástavbu rodinných domov, strednú školu ako aj nákupné centrum. Pravobrežná čast' Tople je v Bardejove zaplavená až do maximálnej vzdialenosti $280 \mathrm{~m}$. Vo východnej časti skúmaného územia, pod mestom Bardejov, dochádza k ohrozeniu budov na okraji obce Bardejovská Nová Ves a zaplaveniu okolitých polí do vzdialenosti až $500 \mathrm{~m}$ od koryta. Smerom k obciam Komárov a Hrabovec sa rozsah zaplavenia nivy znižuje. Koryto má v súčasnosti kapacitu na prevedenie vody o prietoku s pravdepodobnostou opakovania 1 rok, pri ktorej dochádza na niektorých miestach $\mathrm{k}$ zaplaveniu okolitého ripariálneho pásu, predovšetkým v miestach pozostatkov bývalých korýt a morfologických zníženín spôsobených zúžením koryta za posledných 50 rokov. $\mathrm{K}$ vybreženiu dochádza iba v oblasti lužného lesa v oblasti Pod Dúbravou a v oblasti ornej pôdy ned'aleko Bardejovskej Novej Vsi.

\section{Validácia dát}

Priebeh modelovanej vlny bol validovaný v mieste vodomernej stanice $\mathrm{v}$ Bardejove tak, aby sa zhodoval priebeh reálnej a modelovanej krivky prietokov: načasovanie a vel'kost' maximálneho prietoku. Rozsah zaplavenia bol kontrolovaný $\mathrm{s}$ rozsahom zaplavenia podl'a máp povodňového ohrozenia $\mathrm{v}$ mierke 1:10 000 dostupných $\mathrm{z}$ portálu Slovenského vodohospodárskeho podniku (https://mpompr.svp.sk), kde sú dostupné mapy povodňového ohrozenia a mapy povodňového rizika vodných tokov Slovenska, ktoré boli vypracované podl'a Smernice Európskeho parlamentu a Rady 2007/60/ES o hodnotení a manažmente povodňových rizík a Zákona č. 7/2010 o ochrane pred povodňami a jeho novele Zákona č. 71/2015.

Výsledky 2D modelovania $\mathrm{v}$ programe HEC RAS nám poukazujú na vysokú presnost' v porovnaní s povodňovými mapami uverejnenými na portáli SVP (obr. 4). Rozsah zaplavenia a čiara zaplavenia sa výrazne líšia iba v prípade ústia prítokov Kamenec a Šíbska Voda do Tople, ktoré však neboli modelované pre N-ročnost' vody a lokálne v miestach hranice zaplavenia, ktoré sú spôsobené vertikálnou diferenciáciou nivy. 
Obr. 3: Mapa híbok zaplavenia pre oblast' v okolí mesta Bardejov modelovaná pre prietok $\mathrm{Q}_{100}(\mathrm{a}), \mathrm{Q}_{50}(\mathrm{~b})$ a $\mathrm{Q}_{1}$ (c)

Fig. 3: Map of flood depths for the area in the vicinity of Bardejov modeled for $\mathrm{Q}_{100}(\mathrm{a}), \mathrm{Q}_{50}(\mathrm{~b})$ and $\mathrm{Q}_{1}$ (c)
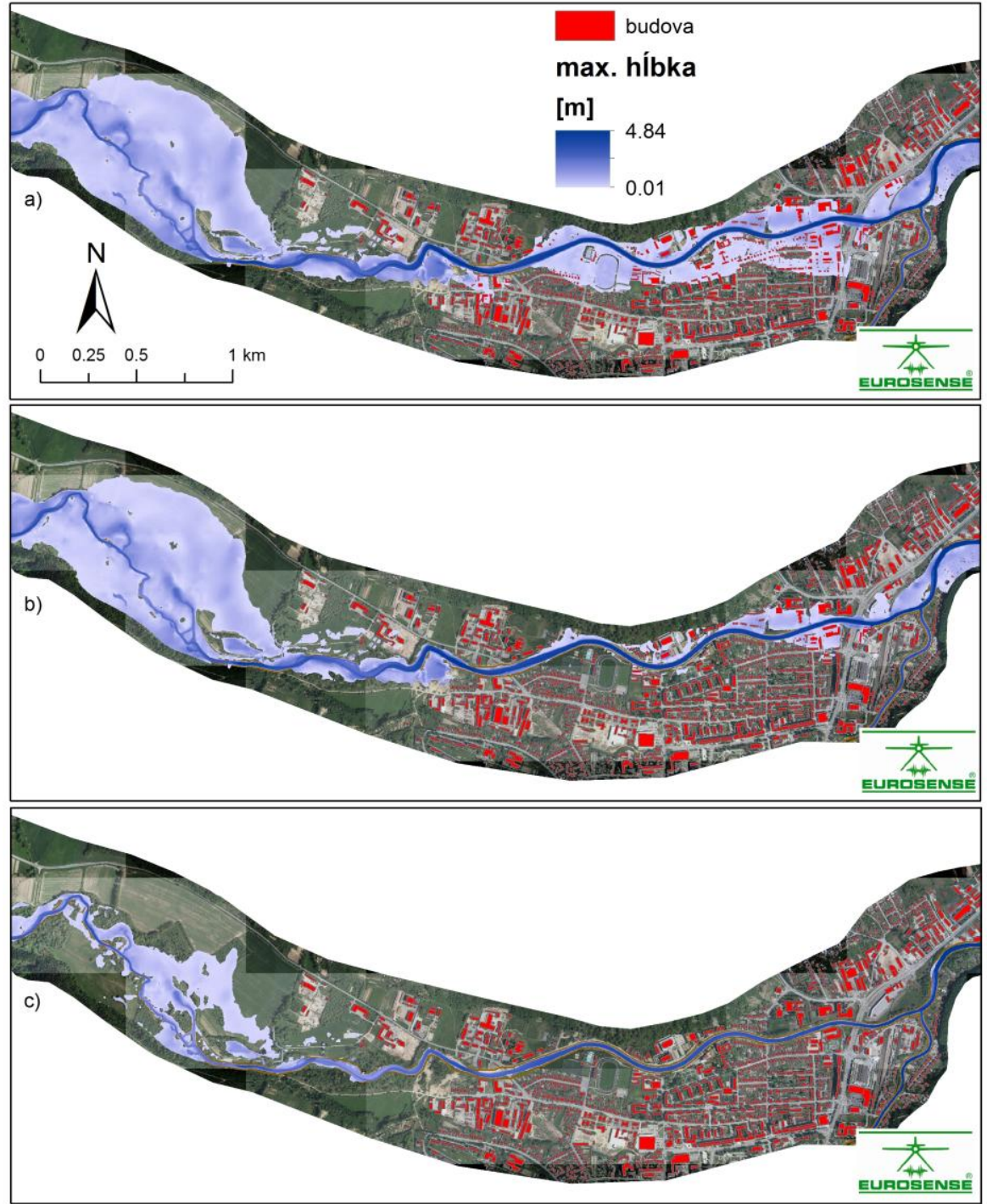

Zdroj: Ortofotomapa CEUROSENSE, s r. o. a Mapový podklad CÚrad geodézie, kartografie a katastra Slovenskej republiky 19-102-646/2018 
Obr. 4: Rozdiel medzi hranicou zaplavenia pre prietok $\mathrm{Q}_{100}$ na troch vybraných úsekoch Tople medzi hydrodynamickým modelovaním v HEC RASe a povodňovými mapami $\mathrm{v}$ mierke $1: 10 \quad 000 \mathrm{z}$ portálu Slovenského vodohospodárskeho podniku

Fig. 4: Difference between the flood boundary for $\mathrm{Q}_{100}$ at three selected Topla sections between hydrodynamic modeling in HEC RAS and flood maps at a scale of 1:10 000 from portal of the Slovak Water Management Enterprise

a)
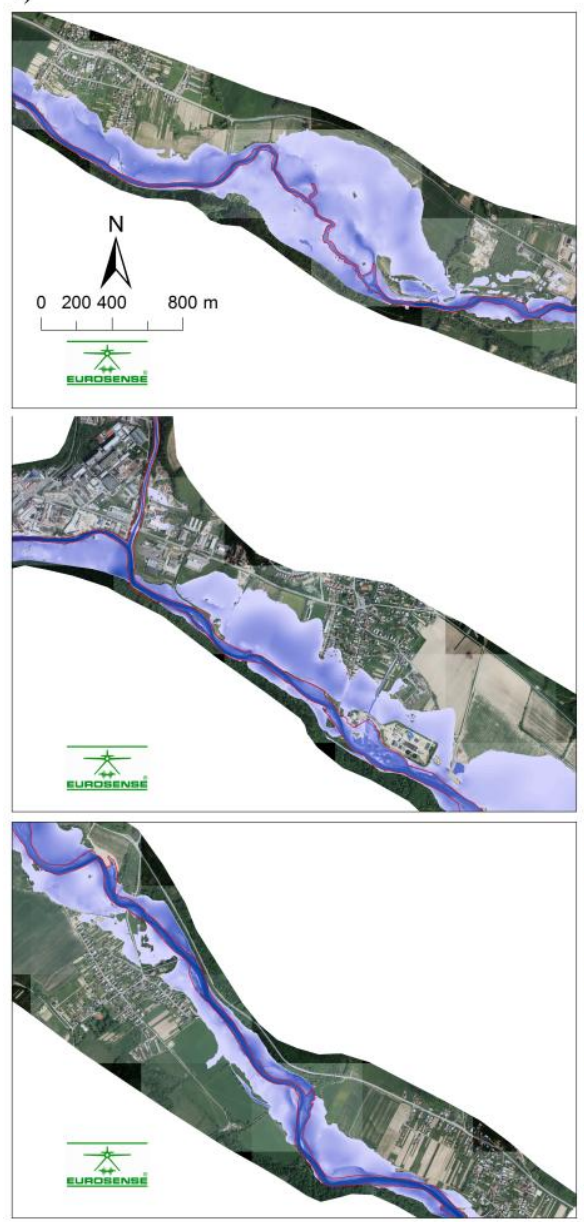

Zdroj: Ortofotomapa CEUROSENSE, s r. o. a mapy povodňového ohrozenia z https://mpompr.svp.sk b)
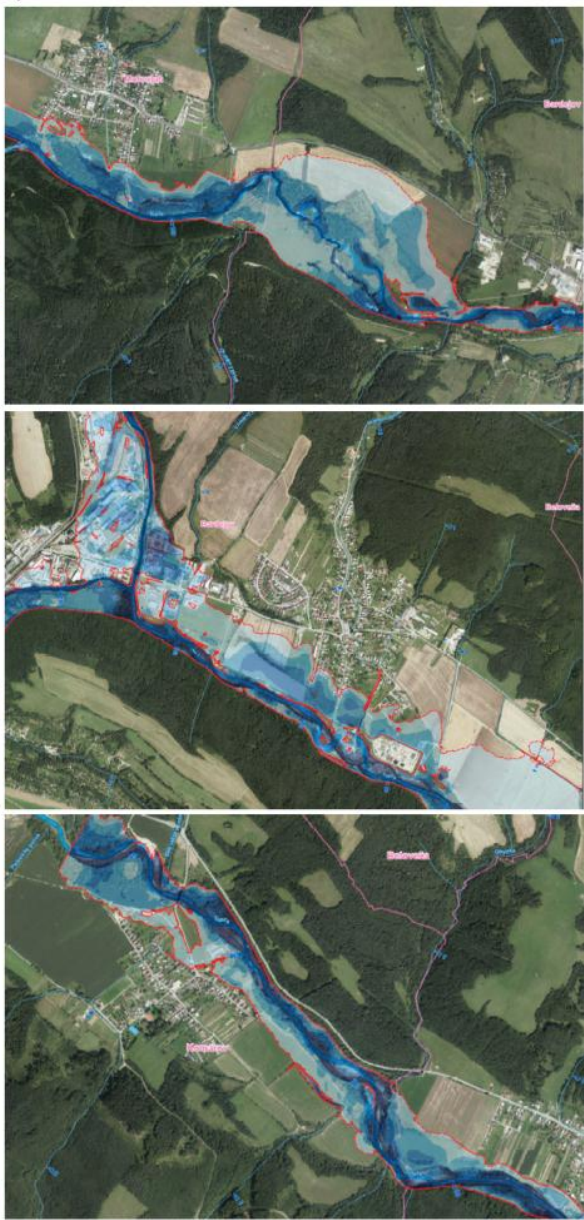


\section{Diskusia}

V dlhodobom horizonte sú $\mathrm{v}$ sledovanom úseku vodného toku viditel'né výrazne zmeny v morfológii koryta a ripariálnej vegetácie, čo vedie aj k zmene hydraulických parametrov povodňovej vlny. Aj ked' $\mathrm{v}$ našom výskume bol modelovaný prietok 100-ročnej povodne z roku 2010, digitálny model, ako aj batymetria koryta odzrkadl'ujú stav až po výraznej morfologickej zmene, ktorú táto povodeň spôsobila. Na niektorých miestach došlo vplyvom laterálnej dynamiky $\mathrm{k}$ rozšíreniu koryta až o $250 \mathrm{~m}$ (Lehotský et al., 2016), čo viedlo k tomu, že koryto bolo schopné previest' skoro celú kapacitu 100-ročnej povodne, čo skresl'uje rozsah modelovanej povodne z roku 2010. Ako uvádza Rusnák et al. (2016), tak dynamická rieka ako je Topl'a, môže koryto výrazne remodelovat' po každej povodni a presunút' prúdnicu o desiatky metrov. Preto je pri dynamických a štrkonosných riekach nevyhnutná častejšia revízia súčasného stavu koryta a dôslednejší monitoring jeho morfologických vlastností, ako aj zahrnutie výskumu brehovej erózie do integrovaného manažmentu povodňového rizika. Neregulované dynamické rieky majú značný vplyv na výšku povodňového ohrozenia. Ako uvádzajú Kidová a Lehotský (2012), na Slovensku predstavujú tieto fragmenty dynamických a neregulovaných riek vzácny ekosystém, ktorý treba chránit'; každý technický zásah do koryta vedie $\mathrm{k}$ ich degradácii a strate geodiverzity, ktorá priamo ovplyvňuje biodiverzitu územia. Tieto výsledky potvrdzuje aj modelovanie prietoku s dobou opakovania 1 rok, ktorá poukazuje na značnú plochu inundácie, ktorá je nevyhnutná pre zachovanie tohto ekosystému $\mathrm{V}$ rámci procesu rozhodovania o najvhodnejšej alternatíve na redukciu povodňového rizika treba prihliadat' aj na dynamiku morfológie riečnych korýt. Práve záujem o zachovanie prirodzeného vývoja koryta rieky prináša konflikt $\mathrm{s}$ redukciou zaplavenia $\mathrm{v}$ intraviláne mesta. $\mathrm{V}$ takomto prípade je potrebné do hodnotenia zahrnút' aj alternatívy, ktoré vyhovujú záujmom viacerých strán. Zníženie povodňového rizika je možné dosiahnut' aj individuálnymi opatreniami obyvatel'ov na zníženie zranitel'nosti ako napríklad: vodeodolnost' budovy, možnost' zaplavenia prízemia, včasné varovanie pred povodňou, poistenie voči povodni (APFM, 2007, Harries, Penning-Rowsell, 2010) alebo zmenou využívania zeme a retenčným priestorom mimo mesta (Brouwer, van Ek, 2004). Vplyvom tradičného inžinierskeho prístupu $\mathrm{k}$ riešeniu problematiky povodní sú technické alternatívy verejnost'ou vnímané ako postačujúce (Michaleje a kol. 2016). Účinnost' týchto opatrení je podmienená informovanost'ou verejnosti, ktorá sa tak stáva nevyhnutnou (Wiesenfeld, Sánchez, 2002).

Výsledky modelovania poukazujú na značnú plochu zaplavenia nad a pod mestom Bardejov (miesta s najväčším rozsahom zaplavenej plochy) a vysokú kapacitu upraveného koryta $\mathrm{v}$ intraviláne mesta prevádzat' povodňové prietoky. $\mathrm{Tu}$ treba podotknút', že zaplavenie $\mathrm{v}$ Bardejove bolo modelované bez existencie jednotlivých protipovodňových úprav a dokončenie všetkých 3 etáp výrazne 
ovplyvní rozsah zaplavenia (Kupa a kol., 2017). Rozdiely medzi modelom v prostredí HEC RAS a mapami z portálu Slovenského vodohospodárskeho podniku sú výrazné iba v miestach väčších prítokov, ako je Š́bska Voda a Kamenec, čo je spôsobené tým, že $\mathrm{v}$ našom prípade sme sa zamerali iba na 100-ročný prietok v hlavnom koryte Tople. Menšie rozdiely môžu byt' spôsobené presnost'ou vstupných dát. Jedná sa predovšetkým o rozlíšenie a vertikálnu presnost' fotogrametricky odvodeného výškového modelu. Chyby sa vyskytujú predovšetkým $v$ miestach hustého zápoja vegetácie, kde fotogrametria nedokáže zachytit' lokálne denivelácie a $\mathrm{v}$ oblastiach pod vodnou hladinou, kde batymetria koryta bola vytvorená interpoláciou priečnych profilov. Simulácia hydrodynamiky (2D simulácia) bola vykonaná v prostredí HEC RAS 5.0.1., ktorý sa považuje za robustný a spol'ahlivý vol’ne dostupný hydraulický modelovací softvér.

\section{Záver}

Identifikácia rozsahu zaplavenia vodného toku Topla v okolí mesta Bardejov pomocou hydrodynamického 2D modelovania odhalila, že koryto má $\mathrm{v}$ súčasnosti kapacitu na prevedenie vody o prietoku $\mathrm{s}$ pravdepodobnost'ou opakovania 1 rok $\left(\mathrm{Q}_{1}\right)$. Hoci i tieto pomerne malé prietoky zapríčiňujú značne vel'ký rozsah zaplavenia nivy (okolie ripariálneho pásu, bývalé korytá, morfologické zníženiny), najväčšia plocha zaplavenia bola identifikovaná pri storočnom prietoku $\left(\mathrm{Q}_{100}\right)$ nad Bardejovom v časti Pod Dúbravou pri zaplavení viacerých studní vodných zdrojov. V okolitých dedinách (Tarnov, Rokytov, Mokroluh) však rovnako storočná voda zaplavením ohrozovala záhrady a hospodárske budovy. Porovnanie povodňových máp Slovenského vodohospodárskeho podniku $\mathrm{s}$ rozsahom zaplavenia $2 \mathrm{D}$ modelovania $\mathrm{v}$ prostredí HEC RAS poukazuje na vysokú presnost' nášho modelu. Najmarkantnejšie rozdiely boli zaznamenané iba $\mathrm{v}$ miestach väčších prítokov (Š́́bska Voda, Kamenec) a lokálne $\mathrm{v}$ miestach $\mathrm{s}$ výraznou vertikálnou diferenciáciou nivy. Znalost' dlhodobého vývoja morfológie koryta, identifikácia procesov $\mathrm{v}$ ňom prebiehajúcich, hydraulické modelovanie, ako aj intenzívna komunikácia medzi lokálnymi alebo štátnymi orgánmi, obcami, mimovládnymi organizáciami a vedcami, je hlavná výzva pre pochopenie a porozumenie riečnych ekosystémov do budúcnosti. Užšia spolupráca je dôležitá pre aplikáciu takýchto zásahov, ktoré majú minimálne dôsledky na ekologickú kvalitu ekosystémov a zároveň minimalizujú negatívne dôsledky povodní ako prírodnej hrozby.

\section{Pod'akovanie}

Príspevok bol riešený s finančnou podporou Vedeckej grantovej agentúry Ministerstva školstva, vedy, výskumu a športu Slovenskej republiky a Slovenskej akadémie vied (VEGA) čislo 2/0098/18. Použité dáta boli zakúpene v rámci 
projektu Danube Region Strategy START 12_PA05-C2 MORCHFLOOD. Ortofotomapa a digitálny model bol zakúpený od firmy CEUROSENSE, $s$ r. o. Hydrologické dáta poskytol Slovenský hydrometeorologický ústav. Údaje z databázy ZB GIS poskytol Úrad geodézie, kartografie a katastra Slovenskej republiky v rámci zmluvy 19-102-646/2018.

\section{Literatúra}

APFM. 2004. Integrated Flood Management. APFM Technical Documents No. 1. 2004. World Meteorological Organization and Global Water Partnership, Geneva. 28 p.

APFM. 2007. Social Aspects and Stakeholder Involvement in Integrated Flood Management. APFM. Technical Documents 2007. World Meteorological Organization and Global Water Partnership, Geneva. 100 p.

BORDEN, K. A. - SCHMIEDTLEIN, C. M. - EMRICH, T. CH. - PIEGROSCH, W. W. - CUTTER, L. S. 2007. Vulnerability of U. S. Cities to Environmental Hazards. In Journal of Homeland Security and Emergency Management. ISSN 1547-7355, 2007, vol. 4, no. 2, pp. 1-21.

BOUMA, J. J. - FRANCOIS, D. - TROCH, P. 2005. Risk assessment and water management. In Environmental Modeling \& Software. ISSN 1364-8152, 2005, vol. 20, no. 2, pp. 141-151.

BROUWER, R. - van EK, R. 2004. Integrated ecological, economic and social impact assessment of alternative flood control policies in the Netherlands. In Ecological Economics. ISSN 0921-8009, 2004, vol. 50, no. 1, pp. 1-21.

DAMBORSKÁ, I. - GERA, M. - MELO, M. - LAPIN, M. - NEJEDLÍK, P. 2016. Changes in the daily range of the air temperature in the mountainous part of Slovakia within the possible context of global warming. In Meteorologische Zeitschrift. ISSN 0941-2948, 2016, vol. 5, no. 1, pp. 17-35.

FULLER, I. C. 2005. February floods in the lower North Island, 2004: Catastrophe - causes and consequences. In New Zealand Geographer. ISSN 1745-7939, 2005, vol. 61, pp. 40-50.

HOOKE, J. M. 1979. An analysis of the processes of river bank erosion. In Journal of Hydrology. ISSN 0022-1694, 1979, vol. 42, pp. 39-62.

HOOKE, J. M. 2003. River meander behaviour and instability: A framework for analysis. In Transactions of the Institute of British Geographers. ISSN 14755661, 2003, vol. 28, pp. 238-253.

IPCC. 2014. Summary for policymakers. In Climate Change 2014: Impacts, Adaptation, and Vulnerability. Part A: Global and Sectoral Aspects. Contribution of Working Group II to the Fifth Assessment Report of the Intergovernmental Panel on Climate Change. Cambridge University Press: Cambridge, UK and New York, NY, pp. 1-32.

KIDOVÁ, A. - LEHOTSKÝ, M. 2012. Časovo-priestorová variabilita morfológie 
divočiaceho a migrujúceho vodného toku Belá. In Geografický časopis. ISSN 0016-7193, 2012, roč. 64, č. 4, s. 311-333.

KUPA, J. - ŠOLTÉSZ, A. - KOLESÁROVÁ, E. - JANÍK, A. 2017. Hydraulické posúdenie protipovodňovej ochrany mesta Bardejov. In Manažment povodí a extrémne hydrologické javy : zborník príspevkov, 2017, Vyhne. ISBN 9788089740161.

LEHOTSKÝ, M. - RUSNÁK, M. - KIDOVÁ, A. 2016. Application of remote sensing and the GIS in interpretation of river geomorphic response to floods. In Radecki-Pawlik, A., Pagliara, S., Hradecky, J. (eds.): Open Channel Hydraulics, River Hydraulic Structures and Fluvial Geomorphology: for engineers, geomorphologists and physical geographers. CRC Press, Portland, 2017, pp. 388-399. ISBN 978-14-9873-08-22

MERZ, B. - AERTS, J. - ARNBJERG-NIELSEN, K. - BALDI, M. - BICHET, A. - BLOCHSL, G. - BOUWER, M. L. - BRAUER, A. - CIOFFI, F. DELGADO, M. J. - GOCHT, M. - GUZZETTI, F. - HARRIGAN, S. HIESCHBOECK, K. - KILSBY, C. - KRON, W. - KWON, H. H. - LALL, U. - MERZ, R. - NISSEN, K. - SALVATTI, P. - SWIERCZYNSKI, T. ULBRICH, U. - VIGLIONE, A. - WARD, J. P. - WEILER, M. - WILHELM, B. - NIED, M. 2014. Floods and Climate: emerging perspectives for flood risk assessment and management. In Natural Hazards and Earth System Sciences. ISSN 1561-8633, 2014, vol. 14, no. 7, pp. 1921-1942.

MICHALEJE, L. - SOLÍN, L. - SLÁDEKOVÁ MADAJOVÁ, M. 2016. Percepcia povodňového rizika obyvatel'mi a jej postavenie v právnom systéme Slovenska: prípadová štúdia $\mathrm{v}$ povodí hornej Myjavy, In Geografický časopis. ISSN 0016-7193, 2016, roč. 68, č. 3, s. 227-243.

MILLER, A. J. 1990. Flood hydrology and geomorphic effectiveness in the Central Appalachians. In Earth Surface Processes and Landforms. ISSN 1096-9837, 1990, vol. 15, pp. 119-134.

PIÉGAY, H. - CUAZ, M. - JAVELLE, E. - MANDIER, P. 1997. Bank erosion management based on geomorphological, ecological and economic criteria on the Galaure River, France. In Regulated Rivers: Research \& Management. ISSN 1535-1467, 1997, vol. 13, pp. 433-448.

PIÉGAY, H. - DARBY, S. E. - MOSSELMAN, E. - SURIAN, N. 2005. A Review of Techniques Available for Delimiting the Erodible River Corridor: A Sustainable Approach to Managing Bank Erosion. In River Research and Applications. ISSN 1535-1467, 2005, vol. 21, pp. 773-789.

RUSNÁK, M. - LEHOTSKÝ, M. 2014. Povodne, brehová erózia a laterálne presúvanie koryta štrkonosných kl’ukatiacich vodných tokov (prípadová štúdia tokov Topl'a a Ondava). In Acta Hydrologica Slovaca. ISSN 1335-6291, 2014, roč. 15 , č. 2, s. 424-433.

RUSNÁK, M. - LEHOTSKÝ, M. - KIDOVÁ, A. 2016. Channel migration inferred from aerial photographs, its timing and environmental consequences as 
responses to floods: a case study of the meandering Topla River, Slovak Carpathians. In Moravian Geographical Reports. ISSN 1210-8812, 2016, vol. 24 , no. 3, pp. 32-43.

SOLÍN, L. - SLÁDEKOVÁ MADAJOVÁ, M. - MICHALEJE, L. 2018. Vulnerability assessment of households and its possible reflection in flood risk management. In International Journal of Disaster Risk Reduction. [online]. 2018, in press [cit. 2018-03-05]. Dostupné na internete: <https://www.sciencedirect.com/science/article/pii/S2212420918300712>. ISSN 1525-321X.

UN/ISDR. 2004. Living with Risk. A global review of disaster reduction initiatives. United Nations - International Strategy for Disaster Reduction, 2004 Version, Volume 1, United Nations Publications, 430 p. ISBN 92-1-101064-0.

VALENT, P. - RONČÁK, P. - MALIARIKOVÁ, M. - KOHNOVÁ, S. SZOLGAY, J. - HLAVČOVÁ, K. 2017. Posúdenie vplyvu využitia územia a manažmentu na tvorbu odtoku v povodí Myjavy. In Acta Hydrologica Slovaca. ISSN 1335-6291, 2017, roč. 18, č. 2, s. 165-173.

VOJTEK, M. 2014. Povodňová hrozba a povodňové riziko na priklade povodia Vyčomy. Nitra: Univerzita Konštantína Filozofa v Nitre, 2014. 238 s. ISBN 978-80-558-0630-3.

WIESENFELD, E. - SÁNCHEZ, E. 2002. Sustained participation: a community based approach to addressing environmental problems. In Bechtel, B. R., Churchman, A. (eds.). Handbook of Environmental Psychology. New York: John Wiley \& Sons, pp. 629-646. ISBN 978-0-471-40594-8.

WYŽGA, B. 1993. River response to channel regulation: Case study of the Raba river, Carpathians, Poland. In Earth Surface Processes and Landforms. ISSN 0197-9337, 1993, vol. 18, no. 6, pp. 541-556.

\section{D INUNDATION MODELING OF GRAVEL-BED TOPLA RIVER (WESTERN CARPATHIANS)}

\section{Summary}

It is widely recognized that attention of scientific and public community rapidly increases on floods and bank erosion risk research. The main aim of the paper is to identify inundation area of the laterally unstable, gravel-bed Topl'a River near Bardejov based on 2D modeling by using HEC RAS software and compare the accuracy of inundation with state flood hazard maps. Hydraulic modeling was performed for 7 different discharges defined base on $\mathrm{N}$-year recurrence interval $\left(\mathrm{Q}_{1}, \mathrm{Q}_{2}, \mathrm{Q}_{5}, \mathrm{Q}_{10}, \mathrm{Q}_{20}, \mathrm{Q}_{50}, \mathrm{Q}_{100}\right)$. Model was calibrated by adjusting Manning's n model parameters. Increasing and decreasing of Manning's values impacts on stage increase/decrease, peak discharge and travel time. Manning's was calibrated for timing of flood peak and for value of maximum flood 
peak. The result pointed to high extent of flooding area for 100-year floods event, which equal to 473.20 ha and 376.53 ha was the flooding area outside the current channel. The maximum depth of water for the Q100 was $4.5 \mathrm{~m}$ on floodplain and $4.8 \mathrm{~m}$ in the channel. The average depth of water on floodplain was $70 \mathrm{~cm}$, and 2.8 $\mathrm{m}$ in channel. Floodplain inundation and average water depth for $\mathrm{Q}_{1}$ floods decrease to 160.8 ha and $50 \mathrm{~cm}$ on floodplain or $1.6 \mathrm{~m}$ in the channel. The results point to the largest flooded area is located above and below town Bardejov and the high capacity channelization in the town's intravilan can transfer $\mathrm{Q}_{50}$ flood discharges. The inundation was checked with an official flood hazard maps (1:10 000) available from the Slovak Water Management Enterprise portal (https://mpompr.svp.sk). The results of $2 \mathrm{D}$ modeling in the HEC RAS point to a high accuracy of our modeling compared with the official flood risk maps (Figure 4). In the case of Topla River 100-year floods was modeled from 2010 hygrograms, but digital elevation model as well as the bathymetry of the channel reflect the situation after this extreme flood event. During this event channel width expanded up to $250 \mathrm{~m}$ (Lehotský et al., 2016) what led to increasing the channel capacity and decreasing inundation area. Knowledge of the long-term evolution of channel morphology, channel processes and hydraulic modeling with intensive communication between local and state water authorities, municipalities, nongovernmental organizations and scientists is a major challenge for the good management of river ecosystems in the future. Closer cooperation is important for the implementation of such interventions that have minimal implications for the ecological quality of ecosystems and minimizing the negative consequences of floods as a natural hazard.

Mgr. Miloš Rusnák, PhD.

Ing. Anna Kidová, PhD.

Mgr. Lukáš Michaleje

Geografický ústav SAV

Štefánikova 49, 81473 Bratislava

E-mail: geogmilo@savba.sk,geogkido@savba.sk,geoglumi@savba.sk 